\title{
Temperature sensitivity of carbon decomposition in soil aggregates along a climatic gradient
}

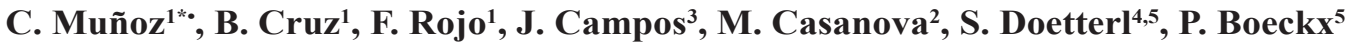 \\ and E. Zagal ${ }^{1 \cdot}$ \\ - These authors contributed equally to this work \\ ${ }^{1}$ Department of Soils and Natural Resources, Faculty of Agronomy, Universidad de Concepción, Chillán, \\ Chile. \\ ${ }^{2}$ Department of Engineering and Soils, Faculty of Agronomic Sciences, Universidad de Chile, Santiago, Chile. \\ ${ }^{3}$ Department of Animal Production, Faculty of Agronomy, Universidad de Concepción. Chillán, Chile. \\ ${ }^{4}$ Institute of Geography, University of Augsburg, Alter Postweg 118, 86135 Augsburg, Germany. \\ ${ }^{5}$ Department of Applied Analytical and Physical Chemistry, Ghent University, Coupure Links 653, 9000 Gent, \\ Belgium.*Corresponding author: cristinamunoz@udec.cl
}

\begin{abstract}
Global warming affects the carbon (C) pools in terrestrial ecosystems, accelerating biological processes that feed back into the phenomenon of climate change. Globally, grassland ecosystems accumulate large quantities of organic $\mathrm{C}$ into soils and are considered a corner stone for global warming mitigation. The aim of this study was to evaluate the temperature sensitivity of $\mathrm{C}$ decomposition in different soil aggregate fractions in grassland ecosystems across a north-south latitudinal gradient in Chile. Soil samples were collected from Mediterranean semi-arid (MSA; $32^{\circ} 31^{\prime}$ to $34^{\circ} 19^{\prime}$ ' south latitude), temperate semi-oceanic (TSO; $35^{\circ} 36^{\prime}$ to $36^{\circ} 27^{\prime}$ south latitude), temperate oceanic (TO; $40^{\circ} 36^{\prime}$ to $43^{\circ} 03^{\prime}$ south latitude) and subpolar semi-oceanic (SPSO; 43 $57^{\prime}$ to $47^{\circ} 40^{\prime}$ ' south latitude) climate zones, and water-stable macroaggregates $(250-2,000 \mu \mathrm{m})$ and free microaggregates $(50-250 \mu \mathrm{m})$ were isolated. Two experiments were performed using short-term incubations (14 days). First, absolute soil respiration and specific soil respiration from isolated aggregates were assessed at $20{ }^{\circ} \mathrm{C}$, and second, the isolated aggregates were incubated at different temperature levels $\left(20-30{ }^{\circ} \mathrm{C}\right.$ for MSA and TSO; $10-20^{\circ} \mathrm{C}$ for TO and SPSO) to quantify the energy of activation $\left(\mathrm{E}_{\mathrm{a}}\right)$ and temperature sensitivity $\left(\mathrm{Q}_{10}\right)$ In general, the results do not provide evidence of differences between soil aggregate fractions in any of the evaluated parameters, but the soils differed across the latitudinal gradient. High absolute respiration rates and specific respiration, which were related to high grassland productivity, were observed in soils from TO and SPSO zones. The $\mathrm{Q}_{10}$ values demonstrated a strong positive correlation with annual precipitation, so $\mathrm{C}$ decomposition in soils from zones with high precipitation exhibits increased temperature sensitivity.
\end{abstract}

Keywords: Energy of activation, $\mathrm{Q}_{10}$, Arrhenius equation, grassland ecosystems, soil fractionation 


\section{Introduction}

Carbon sequestration in soils plays a critical role in the global $\mathrm{C}$ cycle and influences global warming by removing carbon dioxide $\left(\mathrm{CO}_{2}\right)$ from the atmosphere and storing it as soil organic $\mathrm{C}$. With an estimated terrestrial area of 52.5 million $\mathrm{km}^{2}$ (White et al., 2000), or approximately $40 \%$ of the Earth's land surface (excluding Greenland and Antarctica), grasslands have a high potential for C sequestration (White et al., 2000; Mannetje, 2002). It is therefore important to understand the key drivers of $\mathrm{C}$ stabilization in these ecosystems, but a lack of evidence limits the full understanding and accurate prediction of the long-term impacts of climate change on soil C storage (e.g., $\mathrm{Xu}$ et al., 2010).

The effects of changing temperatures on $\mathrm{C}$ stabilization in soil aggregates and the mechanisms governing this process remain largely unknown, which leads to large uncertainties in the prediction of the capacities of soils to stabilize $\mathrm{C}$ in a warming world. Recent studies have reported different and sometimes opposing views on the sensitivity of soil organic C decomposition to temperature (Giardina and Ryan, 2000; Davidson and Janssens, 2006; von Lützow and Kögel-Knabner, 2009), and, in fact, no consensus currently exists on the sensitivity of $\mathrm{C}$ decomposition to temperature increases. The C-quality temperature (CQT) hypothesis predicts that the temperature sensitivity of microbial decomposition should increase with increasing activation energy $\left(\mathrm{E}_{\mathrm{a}}\right)$, so recalcitrant substrates (i.e., those that require high $\mathrm{E}_{\mathrm{a}}$ for their decomposition) should typically be more sensitive to changes in temperature than more labile substrates (Craine et al., 2010). In general, an in- crease in temperature within the mesophilic temperature range $\left(10\right.$ to $\left.25^{\circ} \mathrm{C}\right)$ activates microbial biomass, suggesting selective pressure and/or adaptation of soil microorganisms at this temperature (Voroney, 2007). The sensitivity of heterotrophic microorganisms to temperature can be determined by the Arrhenius equation and $\mathrm{Q}_{10}$ value, which are valuable concepts that have received growing interest in the context of global warming due to their ability to predict interactions between different soil C pools. However, soil C stability involves complex interactions between biological (Guidi et al., 2013) and mineral components (Doetterl et al., 2015), and it is influenced by the three dimensions of the spatial distribution of soil C (Meersmans et al., 2009): (i) biochemical recalcitrance of $\mathrm{C}$ molecules (Stockmann et al., 2013), (ii) formation of clay-humic complexes (Six et al., 2002; Matus et al., 2014; Takahashi and Dahlgren, 2016) and (iii) physical protection of $\mathrm{C}$ by the formation and stabilization of aggregate structures (Lehmann et al., 2007).

The physical protection of $\mathrm{C}$ within aggregates has received much attention in the field of agricultural sciences. First, studies show that physical protection can preserve the $\mathrm{C}$ in soils for decades to centuries, depending on the physiochemistry of the mineral and organic particles (Onweremadu et al., 2007; Takahashi and Dahlgren, 2016) and the location of the $\mathrm{C}$ within soil aggregates (Yoo et al., 2011). Second, the decay and $\mathrm{C}$-stabilization of plant and animal residues influence the formation of aggregate structure (Blanco-Canqui and Lal, 2004), through its influence on the transport of water and air into soils as 
well as C sequestration (Six et al., 2002). Therefore, assessing the effect of environmental change on $\mathrm{C}$ stability in different aggregate fractions is relevant to understanding the effects of global warming on soils. Overall, the sensitivity of soil organic $\mathrm{C}$ decomposition to temperature can have a strong impact on the capacity of the soil to retain $\mathrm{C}$, and it might be critical to determining whether the soil acts as a $\mathrm{C}$ source or sink. Using soils from reforested and deforested sites, Zhang et al. (2015) determined that $\mathrm{C}$ decomposition rates vary with climatic factors, reporting that $\mathrm{C}$ decomposition increased with increasing annual mean temperature and precipitation. However, temperature sensitivity experiments along largescale geo-climatic gradients (e.g., with increasing precipitation and among different soil types) are largely unknown.

Thus, the study of the temperature sensitivity of different $\mathrm{C}$ pools in macro- and microaggregates is relevant to understanding the real contribution of soils as a $\mathrm{C}$-sequestration strategy and the potential feedback effects on terrestrial $\mathrm{C}$ reservoirs that produce global warming.

We hypothesize that the $\mathrm{C}$ pools contained in different sizes of soil aggregates could vary in their temperature sensitivity to decomposition along a climatic gradient, so the objective of the present study was to investigate the temperature sensitivity of $\mathrm{C}$ decomposition in soil aggregates from grassland ecosystems over such a gradient.

\section{Materials and Methods}

\subsection{Study sites}

The study was conducted in mineral soils of natural grasslands in central and southern Chile, from $32^{\circ} 31^{\prime}$ to $47^{\circ} 40^{\prime}$ south latitude and $71^{\circ} 15^{\prime}$ ' to $72^{\circ} 21^{\prime}$ west longitude, and it incorporated the climatic conditions and soil types representative of each climate zone within the gradient.

The study sites were grouped according to climatic characteristics as follows: Mediterranean semi-arid (MSA) soils from Series Catapilco, Clarillo and Pimpinela; temperate semi-oceanic (TSO) soils from Series Bramaderos, Chanco and Santa Bárbara; temperate oceanic (TO) soils from Series Bahía Mansa, Chapo, Mayamó and Aituí; and subpolar semi-oceanic (SPSO) soils from Series La Tapera, Simpson and Cochrane (World Clim-Global Climate Data,

http://www.worldclim.org/current; see also Doetterl et al., 2015).

The chemical characterization and climatic conditions of the soil sites are shown in Table 1; soils were classified according to the Soil Survey Staff (1999) and World Reference Base for Soil Resources (IUSS Working Group WRB., 2015).

The zone with the lowest annual precipitation is MSA, which includes the northernmost sampling sites (Catapilco, Clarillo and Pimpinela), with an annual mean precipitation of $458 \mathrm{~mm}$, while the zone with the highest annual mean precipitation is TO (Bahía Mansa, Chapo, Mayamó and Aituí) with an average of 2,207 $\mathrm{mm}$. The warmest sites are located in MSA, with an annual mean temperature of $15.2{ }^{\circ} \mathrm{C}$, and the coldest sites are located in the SPSO climate zone (La Tapera, Simpson and Cochrane), with an average temperature of $4.4^{\circ} \mathrm{C}$. 
Table 1a. Identification of the study sites and characterization of the soils.

\begin{tabular}{|c|c|c|c|c|c|c|c|c|c|c|c|c|}
\hline \multirow{2}{*}{$\begin{array}{l}\text { Climate } \\
\text { zone }^{1}\end{array}$} & \multirow{2}{*}{$\begin{array}{l}\text { Soil } \\
\text { Series }\end{array}$} & \multicolumn{2}{|c|}{ Coordinates } & \multirow{2}{*}{$\begin{array}{l}\text { MAP } \\
\mathrm{mm}\end{array}$} & \multirow{2}{*}{$\begin{array}{l}\text { MAT } \\
{ }^{\circ} \mathrm{C}\end{array}$} & \multirow{2}{*}{$\begin{array}{c}\text { Soil } \\
\text { Taxonomy* }\end{array}$} & \multirow{2}{*}{$\begin{array}{c}\text { WRB } \\
\text { (ISRIC) }\end{array}$} & Clay & $\mathrm{N}_{\mathrm{t}}$ & \multirow[t]{2}{*}{$\mathrm{pH}_{\mathrm{w}}$} & \multirow{2}{*}{$\begin{array}{l}\mathrm{P}_{\text {Olsen }} \\
* *\end{array}$} & \multirow{2}{*}{$\begin{array}{l}\Sigma \\
\text { bases } \\
* * *\end{array}$} \\
\hline & & South Lat. & West Long. & & & & & 0 & & & & \\
\hline \multirow[t]{3}{*}{ MSA } & Catapilco & $-32^{\circ} 31^{\prime} 35^{\prime \prime}$ & $-71^{\circ} 15^{\prime} 39^{\prime \prime}$ & 325 & 17.0 & $\begin{array}{l}\text { Udollic } \\
\text { Albaqualf }\end{array}$ & Planosol & 16.1 & 0.21 & 5.6 & 16.65 & 7.42 \\
\hline & Clarillo & $-33^{\circ} 40^{\prime} 49^{\prime \prime}$ & $-70^{\circ} 35^{\prime} 09^{\prime \prime}$ & 500 & 14.4 & $\begin{array}{l}\text { Ultic } \\
\text { Haploxeroll }\end{array}$ & $\begin{array}{l}\text { Kastanozem } \\
\text { / Chernozem }\end{array}$ & 21.9 & 0.19 & 7.5 & 36.69 & 19.64 \\
\hline & Pimpinela & $-34^{\circ} 19^{\prime} 26^{\prime \prime}$ & $-70^{\circ} 43^{\prime} 47^{\prime \prime}$ & 549 & 14.2 & $\begin{array}{l}\text { Mollic } \\
\text { Haploxeralf }\end{array}$ & $\begin{array}{l}\text { Haplic } \\
\text { Luvisol/ } \\
\text { Haplic } \\
\text { Lixisol }\end{array}$ & 15.2 & 0.16 & 6.4 & 9.02 & 14.32 \\
\hline \multirow[t]{3}{*}{ TSO } & Bramadero & $-35^{\circ} 36^{\prime} 48^{\prime \prime}$ & $-71^{\circ} 18^{\prime} 53^{\prime \prime}$ & 1033 & 12.8 & $\begin{array}{l}\text { Humic } \\
\text { Haploxerand }\end{array}$ & Andosol & 16.6 & 0.40 & 6 & 11.27 & 12.01 \\
\hline & Chanco & $-35^{\circ} 44^{\prime} 31^{\prime \prime}$ & $-72^{\circ} 31^{\prime} 11^{\prime \prime}$ & 835 & 13.2 & $\begin{array}{l}\text { Ultic } \\
\text { Argixeroll }\end{array}$ & $\begin{array}{l}\text { Luvic } \\
\text { Kastanozem } \\
\text { / Luvic } \\
\text { Chernozem }\end{array}$ & 31.3 & 0.15 & 6.3 & 14.56 & 7.36 \\
\hline & $\begin{array}{l}\text { Sta. } \\
\text { Bárbara }\end{array}$ & $-36^{\circ} 27^{\prime} 30^{\prime \prime}$ & $-71^{\circ} 41^{\prime} 50^{\prime \prime}$ & 1321 & 12.0 & $\begin{array}{l}\text { Typic } \\
\text { Haploxerand }\end{array}$ & Andosol & 20.0 & 0.52 & 6.1 & 6.11 & 2.69 \\
\hline TO & $\begin{array}{l}\text { Bahía } \\
\text { Mansa }\end{array}$ & $-40^{\circ} 36^{\prime} 32^{\prime \prime}$ & $-73^{\circ} 44^{\prime} 56^{\prime \prime}$ & 1848 & 11.1 & $\begin{array}{l}\text { Oxic } \\
\text { Dystrudept }\end{array}$ & $\begin{array}{l}\text { Cambisol } \\
\text { /Dystric }\end{array}$ & 20.0 & 0.59 & 5.2 & 3.94 & 1.46 \\
\hline
\end{tabular}

Table1b. Identification of the study sites and characterization of the soils.

\begin{tabular}{|c|c|c|c|c|c|c|c|c|c|c|c|c|}
\hline & Chapo & $-41^{\circ} 25^{\prime} 28^{\prime \prime}$ & $-72^{\circ} 38^{\prime} 53^{\prime \prime}$ & 2332 & 10.0 & $\begin{array}{l}\text { Typic } \\
\text { Hydrudand }\end{array}$ & $\begin{array}{l}\text { Hydric } \\
\text { Andosol }\end{array}$ & 7.8 & 0.46 & 5 & 6.03 & 3.06 \\
\hline & Mayamó & $-42^{\circ} 03^{\prime} 07^{\prime \prime}$ & $-73^{\circ} 47^{\prime} 58^{\prime}$ & 2414 & 10.3 & $\begin{array}{l}\text { Acrudoxic } \\
\text { Durudand }\end{array}$ & $\begin{array}{l}\text { Petroduric } \\
\text { Andosol }\end{array}$ & 4.6 & 0.71 & 4.7 & 5.36 & 4.91 \\
\hline & Aituí & $-43^{\circ} 03^{\prime} 29^{\prime}$ & $-73^{\circ} 36^{\prime} 48^{\prime \prime}$ & 2232 & 10.8 & $\begin{array}{l}\text { Hydric } \\
\text { Fulvudand }\end{array}$ & $\begin{array}{l}\text { Fulvic } \\
\text { Andosol }\end{array}$ & 7.9 & 1.31 & 5 & 7.31 & 6.59 \\
\hline \multirow[t]{3}{*}{ SPSO } & La Tapera & $-43^{\circ} 57^{\prime} 50^{\prime \prime}$ & $-72^{\circ} 23^{\prime} 47^{\prime \prime}$ & 1079 & 7.2 & $\begin{array}{l}\text { Typic } \\
\text { Hapludand }\end{array}$ & Andosol & 9.8 & 0.65 & 6 & 30.11 & 7.31 \\
\hline & Simpson & $-45^{\circ} 48^{\prime} 58^{\prime}$ & $-71^{\circ} 55^{\prime} 53^{\prime \prime}$ & 1524 & 3.2 & $\begin{array}{l}\text { Andic } \\
\text { Dystrudept }\end{array}$ & $\begin{array}{l}\text { Cambisol } \\
\text { /Dystric }\end{array}$ & 9.3 & 0,42 & 6.5 & 2.52 & 7.75 \\
\hline & Cochrane & $-47^{\circ} 40^{\prime} 35^{\prime}$, & $-72^{\circ} 21^{\prime} 16^{\prime \prime}$ & 480 & 2.7 & $\begin{array}{l}\text { Andic } \\
\text { Oxyaquic } \\
\text { Dystrudept }\end{array}$ & $\begin{array}{l}\text { Cambisol } \\
\text { /Dystric }\end{array}$ & 11.3 & 0.45 & 6.4 & 11.3 & 13.01 \\
\hline
\end{tabular}

${ }^{1}$ Climate zone: $\mathrm{MSA}=$ Mediterranean semi-arid, $\mathrm{TSO}=$ Temperate semi-oceanic, $\mathrm{TO}=$ Temperate oceanic, $\mathrm{SPSO}=$ Subpolar semi-oceanic, MAP = Mean annual precipitation, MAT= Mean annual temperature; * Casanova et al. (2013); **P Olsen in $\mathrm{mg} / \mathrm{kg}$, *** $\Sigma$ bases in cmolc/kg. 
The study sites were all under grassland and/or shrubland vegetation to keep $\mathrm{C}$ input as similar as possible, but differences in the type of grassland and the input of organic matter could not be controlled. Biomass production along the transect ranged between 1,000 to $4,500 \mathrm{~kg}$ dry weight ha- ${ }^{-1}$ $\mathrm{yr}^{-1}$ with extreme values of $500 \mathrm{~kg} \mathrm{ha}^{-1} \mathrm{yr}^{-1}$ in hot arid climates and $6,000 \mathrm{~kg} \mathrm{ha}^{-1} \mathrm{yr}^{-1}$ in temperate humid climates (Ruiz, 1996).

\subsection{Sampling and soil analysis}

Three composite samples were collected per study site (one per plot) in fall 2012. At each plot, twenty randomly selected soil cores, which were restricted to the A horizon (0-7 cm soil depth), were taken with a 2-cm-diameter soil drill and pooled to create the composite sample. Samples were sieved $(<2 \mathrm{~mm})$ in the field to remove soil fauna, rocks and fine roots and then thoroughly hand-mixed, placed in plastic bags and transported to the laboratory in several cooler boxes. At the laboratory, the soil samples were air dried and kept frozen at $-18{ }^{\circ} \mathrm{C}$ until the start of the experiments, and chemical characterization of the bulk soil (Table 1) was performed according to Sadzawska et al. (2006). Total C was between 2.25 and $11.9 \%$; total $\mathrm{N}$ ranged from 0.15 to $1.31 \%$; and $\mathrm{pH}$ ranged from 4.7 to 7.5 . The high variability in the chemical properties were to the diverse soil types along the transect. The soil clay content of the bulk soil was determined according to Sandoval et al. (2012).

\subsection{Soil fractionation}

Three replicates of each soil sample were fractionated into stable aggregate fractions of different sizes (Starr et al., 2001) using a rainfall simulator coupled to a sieve shaker (AS 200 Digit, Retsch,
Haan, Germany). A subsample of $200 \mathrm{~g}$ was wetted with distilled water for 5 minutes and then placed into a $250-\mu \mathrm{m}$ steel sieve. Rain was simulated at $50 \mathrm{~mm} \mathrm{hour}^{-1}$ for 10 minutes, which separated the macroaggregates $(250-2000 \mu \mathrm{m})$ and free microaggregates $(50-250 \mu \mathrm{m})$ (Elliot et al., 1986). Soil particle sizes of less than $50 \mu \mathrm{m}$ were not considered in this study, and, similarly, the light fraction separated from the macroaggregates by flotation in water (Balesdent et al., 1991) was discarded because this fresh organic matter is not part of the soil aggregates. The mass recovery of whole soil fractions was more than $90 \%$ of the total bulk soil mass (including the discarded fractions), indicating that the largest portion of the soil mass was aggregated. The total $\mathrm{C}$ and $\mathrm{N}$ contents of the bulk soil and the aggregates were determined by dry combustion.

\subsection{Soil respiration}

Absolute soil respiration was measured by capturing the $\mathrm{CO}_{2}$ produced from the soil incubations. The soil samples $(n=3)$ were conditioned at $60 \%$ water-filled pore space (WFPS) and pre-incubated for 7 days. The incubations were conducted using $20 \mathrm{~g}$ of a soil sample in 50-ml polyethylene tubes with a cap containing a rubber septum for gas sample collection. The incubations for the soil respiration assay were conducted in incubators at $20^{\circ} \mathrm{C}$, keeping soil water content constant to reach the maximum potential respiration for the incubated samples. The gas analyses were performed following the approach described by Plante et al. (2009), in which 4-ml gas samples were collected from the incubation tubes, and the pressure was then re-established by the addition of helium. The gas sample was injected in-line into an $\mathrm{N}_{2}$ gas stream, and the peak heights were measured with an infrared gas analyzer (Licor, model Li-820, USA). 
Following a set of calibrations, peak heights were converted to $\mathrm{CO}_{2}$ concentrations in the tubes, and the rate of soil respiration was then calculated as the slope of the linear equation of the amount of soil respiration accumulated during incubation (3, 5,7 and 14 days).

\subsection{Specific potential respiration}

Absolute soil respiration was used to obtain the specific potential respiration as $\mathrm{CO}_{2}-\mathrm{C}$ per unit of

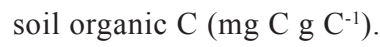

\subsection{Sensitivity of $C$ decay to temperature}

The sensitivity of organic matter decomposition to temperature was based on the differences in the apparent activation energy $\left(\mathrm{E}_{\mathrm{a}}\right)$ and $\mathrm{Q}_{10}$ value.

The Arrhenius equation was used to calculate the $\mathrm{E}_{\mathrm{a}}$ of the chemical reactions that contributed to soil respiration, and the specific potential respiration is described as $k$ in Equation 1.

$$
k=A e^{\frac{-E_{a}}{R T}}
$$

where $A$ is a frequency or pre-exponential factor (it is the theoretical reaction rate constant in the absence of activation energy); $R$ is the gas constant (8.314 $\mathrm{J} \mathrm{K}^{-1} \mathrm{~mol}^{-1}$ ), and $T$ is the temperature in Kelvin. The $\mathrm{E}_{\mathrm{a}}$ was calculated as the slope of the relationship between $-1 / R T$ and the natural logarithm of the specific respiration rates, which were expressed in $\mathrm{kJ} \mathrm{mol}^{-1}$.

The $\mathrm{Q}_{10}$ value was calculated according to Leifeld and Fuhrer (2005) on the basis of soil respiration at two different temperatures, where $K_{1}$ and $K_{2}$ are soil respiration ( $\mathrm{mg} \mathrm{C} \mathrm{g} \mathrm{dry} \mathrm{soil}{ }^{-1}$ ) at $\mathrm{T}_{1}$ and $\mathrm{T}_{2}$, respectively (Equation 2).

$$
Q_{10}=\left(\frac{K_{2}}{K_{1}}\right)^{\left(\frac{10}{T_{2}-T_{1}}\right)}
$$

The temperatures used for MSA and TSO were $\mathrm{T}_{1}$ $=20^{\circ} \mathrm{C}$ and $\mathrm{T}_{2}=30^{\circ} \mathrm{C}$, and for TO and SPSO, they were $\mathrm{T}_{1}=10{ }^{\circ} \mathrm{C}$ and $\mathrm{T}_{2}=20^{\circ} \mathrm{C}$. These conditions were established to induce soil respiration close to the microbial activity potential under different field climatic conditions.

\subsection{Statistical Analysis}

A t-test ( $p \leq 0.05$ ) was used to analyze whether the soil aggregates were significantly different from each other in each climatic zone (MSA, TSO, TO and SPSO). One-way ANOVA and Fisher's LSD (least significant difference) test $(p \leq 0.05)$ were used to evaluate differences in soil respiration, $\mathrm{E}_{\mathrm{a}}$ and $\mathrm{Q}_{10}$ between climatic zones considering each data set as an independent assay (soil aggregate sizes), and Pearson's correlations were calculated to determine the relationships between parameters. INFOSTAT ${ }^{\circledR}$ (Di Rienzo et al., 2011) was used to analyze the data.

\section{Results}

\subsection{Physical fractionation of soil organic $C$}

The proportion of macro- and free microaggregates obtained from each soil type varied considerably (Figure 1). Soils from the MSA and TSO climates 
mainly contained free microaggregates (50-250 $\mu \mathrm{m})$ in a proportion of $32.2 \pm 6.2 \%$ of the total soil mass, while soils from the TO zone presented a higher proportion of macroaggregates (250-2000 $\mu \mathrm{m})$ with an average of $50.2 \pm 5.6 \%$ of the total soil mass (Chapo, Mayamó and Aituí soils). In the SPSO zone, the proportions of macro- and free microaggregates were similar, each presenting $21.9 \pm$ $1.54 \%$ of the total soil mass.

Carbon concentrations were similar (i.e., not significatly different at $p \leq 0.05$ ) between soil aggregate fraction of the same series (Table 2) but the $\mathrm{C}$ concentrations within the soil aggregates in MSA and TSO were lower (average of $3.0 \pm 1.7 \% ; p \leq 0.05$ ) than that obtained for the TO climate zone $(10.0 \pm 2.1 \%)$. Additionally, the relative contribution of each soil aggregate fraction to the total $\mathrm{C}$ mass of the soil (Table 2) demonstrated that macroaggregates contributed between 4 and $84 \%$ of the total $\mathrm{C}$ in the soil. The highest value was observed in the Chapo soil, which had high macroaggregate preservation $(84.34 \%$ of the total $\mathrm{C}$ mass). In the case of free-microaggregates, the $\mathrm{C}$ contribution range was between 16.3 to $38.7 \%$ for all soils.

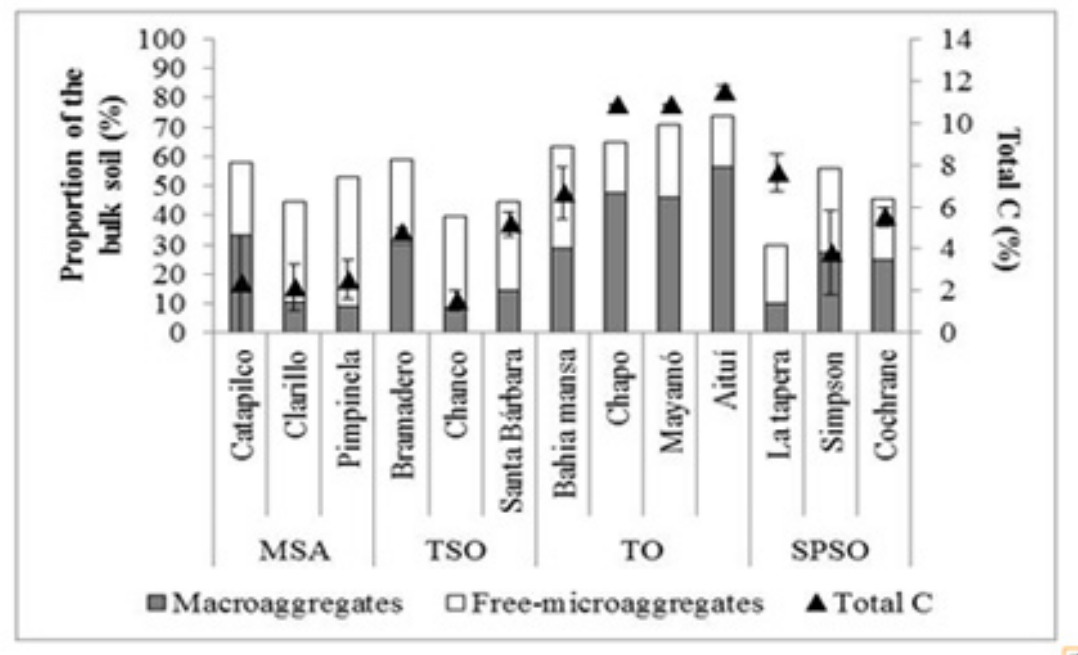

Figure 1. Proportion of macro- and free microaggregates in bulk soil and total $\mathrm{C}$ content in soil aggregates. 
Table 2. Total C (\%) in bulk and aggregate soils, and the contribution of soil aggregates to $\mathrm{C}$ mass as a fraction of the total

\begin{tabular}{|c|c|c|c|c|c|c|}
\hline \multirow[t]{2}{*}{$\begin{array}{c}\text { Climate } \\
\text { zone* }\end{array}$} & \multirow[t]{2}{*}{ Soil series } & \multirow{2}{*}{$\begin{array}{c}\text { Total C } \\
\text { concentration of } \\
\text { bulk soil (\%) }\end{array}$} & \multicolumn{2}{|c|}{$\mathrm{C}$ concentration $(\%)$} & \multicolumn{2}{|c|}{$\begin{array}{l}\text { Relative } \mathrm{C} \text { mass as fraction of total } \\
\qquad(\%)\end{array}$} \\
\hline & & & $\begin{array}{c}\text { Macro } \\
\text { aggregates }\end{array}$ & $\begin{array}{c}\text { Free- } \\
\text { microaggregates }\end{array}$ & $\begin{array}{c}\text { Macro } \\
\text { aggregates }\end{array}$ & $\begin{array}{c}\text { Free- } \\
\text { microaggregates }\end{array}$ \\
\hline \multirow[t]{3}{*}{ MSA } & Catapilco & 2.56 & $0.72 \pm 0.43$ & $3.99 \pm 0.93$ & 9.31 & 38.68 \\
\hline & Clarillo & 2.69 & $1.37 \pm 0.41$ & $2.93 \pm 1.19$ & 5.27 & 37.21 \\
\hline & Pimpinela & 2.25 & $3.21 \pm 0.92$ & $1.86 \pm 0.57$ & 13.04 & 36.44 \\
\hline \multirow[t]{3}{*}{ TSO } & Bramadero & 4.79 & $4.95 \pm 0.24$ & $4.60 \pm 0.63$ & 31.11 & 27.69 \\
\hline & Chanco & 2.52 & $1.18 \pm 0.21$ & $1.88 \pm 0.19$ & 4.09 & 23.00 \\
\hline & Sta. Bárbara & 6.38 & $5.61 \pm 0.10$ & $4.77 \pm 0.70$ & 12.58 & 22.67 \\
\hline \multirow[t]{4}{*}{ TO } & Bahía Mansa & 7.33 & $5.79 \pm 0.51$ & $7.55 \pm 0.53$ & 22.68 & 35.80 \\
\hline & Chapo & 6.16 & $10.87 \pm 0.58$ & $10.83 \pm 0.75$ & 84.34 & 29.70 \\
\hline & Mayamó & 9.54 & $10.83 \pm 0.47$ & $10.90 \pm 0.72$ & 52.49 & 28.23 \\
\hline & Aituí & 11.9 & $11.33 \pm 0.57$ & $11.70 \pm 0.20$ & 53.84 & 16.96 \\
\hline \multirow[t]{3}{*}{ SPSO } & La Tapera & 8.1 & $8.27 \pm 1.07$ & $6.98 \pm 0.85$ & 10.43 & 16.90 \\
\hline & Simpson & 4.76 & $2.39 \pm 0.51$ & $5.24 \pm 0.50$ & 13.81 & 31.56 \\
\hline & Cochrane & 6.66 & $5.82 \pm 0.27$ & $5.22 \pm 0.60$ & 21.70 & 16.31 \\
\hline
\end{tabular}

Climate zone description as in Figure 1.

\subsection{Absolute and specific soil respiration}

Absolute respiration rates (Table 3) for MSA, TSO and SPSO $\left(0.92 \pm 1.52 \mu \mathrm{g} \mathrm{C} \mathrm{g}^{-1} \mathrm{~d}^{-1}\right.$ on average $)$ were not significantly different between soil aggregate fractions, but higher soil respiration was found in the macroaggregates than in the free microaggregates (10.93 $\mu \mathrm{g} \mathrm{C} \mathrm{g}^{-1} \mathrm{~d}^{-1}$ and $5.83 \mu \mathrm{g} \mathrm{C} \mathrm{g}^{-1}$ $\mathrm{d}^{-1}$, respectively) for TO.
The specific soil respirations (Figure 2) from the two soil aggregate sizes were not significantly different ( $p$ $\leq 0.05)$, but MSA (211-714 $\mu \mathrm{g} \mathrm{C} \mathrm{g} \mathrm{C} \mathrm{soil-1)} \mathrm{and} \mathrm{TSO}$ (58-338 $\mu \mathrm{g} \mathrm{C} \mathrm{g} \mathrm{C} \mathrm{soil}{ }^{-1}$ ) presented lower specific soil respirations than soils from TO (1108-3984 $\mu \mathrm{g} \mathrm{C} \mathrm{g}$ $\mathrm{C}$ soil $^{-1}$ ) and SPSO (287-1545 $\mu \mathrm{g} \mathrm{C} \mathrm{g} \mathrm{C} \mathrm{soil-1)} \mathrm{(Fig-}$ ure 2). In addition, the trend in Figure $2 \mathrm{~A}$ suggests that there is a decrease in specific soil respiration with increased precipitation, while in contrast, Figure 2B 
shows an increase in specific soil respiration with increasing precipitation, which is higher and also colder than those values shown for MSA and TSO. Across all sites, the relationship between specific soil respiration and annual precipitation was 0.65 (Pearson correlation; $p \leq 0.05$ ), but no significant correlation was found between this parameter and the mean temperature of each zone.

Table 3. Absolute soil respiration rates $\left(\mu \mathrm{g} \mathrm{C} \mathrm{g}^{-1} \mathrm{~d}^{-1}\right)$ of soil aggregates from different climate zones. Fishers LSD test $(\mathrm{p} \leq 0.05)$; different letters represent statistical significance between climate zones.

\begin{tabular}{|c|c|c|c|c|c|}
\hline Climate zone & Soil & $\begin{array}{l}\text { Macroaggregate } \\
\left(\mu \mathrm{g} \mathrm{C} \mathrm{g}^{-1} \mathrm{~d}^{-1}\right)\end{array}$ & $\begin{array}{l}\text { Mean } \\
\left(\mu \mathrm{g} \mathrm{C} \mathrm{g}^{-1} \mathrm{~d}^{-1}\right)\end{array}$ & $\begin{array}{l}\text { Free-micro } \\
\text { aggregate } \\
\left(\mu \mathrm{g} \mathrm{C} \mathrm{g}^{-1} \mathrm{~d}^{-1}\right)\end{array}$ & $\begin{array}{l}\text { Mean } \\
\left(\mu \mathrm{g} \mathrm{C} \mathrm{g}^{-1} \mathrm{~d}^{-1}\right)\end{array}$ \\
\hline \multirow[t]{3}{*}{ MSA } & Catapilco & 0.10 & \multirow[t]{3}{*}{$0.44 \pm 0.43 b$} & 0.23 & \multirow[t]{3}{*}{$0.28 \pm 0.14 b$} \\
\hline & Clarillo & 0.31 & & 0.44 & \\
\hline & Pimpinela & 0.93 & & 0.17 & \\
\hline \multirow[t]{3}{*}{ TSO } & Bramadero & 0.68 & \multirow[t]{3}{*}{$0.35 \pm 0.28 \mathrm{~b}$} & 0.31 & \multirow[t]{3}{*}{$0.25 \pm 0.15 b$} \\
\hline & Chanco & 0.18 & & 0.08 & \\
\hline & $\begin{array}{l}\text { Santa } \\
\text { Bárbara }\end{array}$ & 0.21 & & 0.35 & \\
\hline \multirow[t]{4}{*}{ TO } & Bahía Mansa & 11.06 & \multirow[t]{4}{*}{$10.93 \pm 4.19 a$} & 3.43 & \multirow[t]{4}{*}{$5.83 \pm 1.63 \mathrm{a}$} \\
\hline & Chapo & 16.14 & & 6.62 & \\
\hline & Mayamó & 5.30 & & 6.30 & \\
\hline & Aituí & 15.37 & & 6.98 & \\
\hline \multirow[t]{3}{*}{ SPSO } & La Tapera & 0.63 & \multirow[t]{3}{*}{$1.21 \pm 0.68 \mathrm{~b}$} & 0.84 & \multirow[t]{3}{*}{$2.22 \pm 1.91 \mathrm{~b}$} \\
\hline & Simpson & 1.04 & & 1.41 & \\
\hline & Cochrane & 1.96 & & 6.67 & \\
\hline
\end{tabular}

*Climate zone description as in Figure 1 


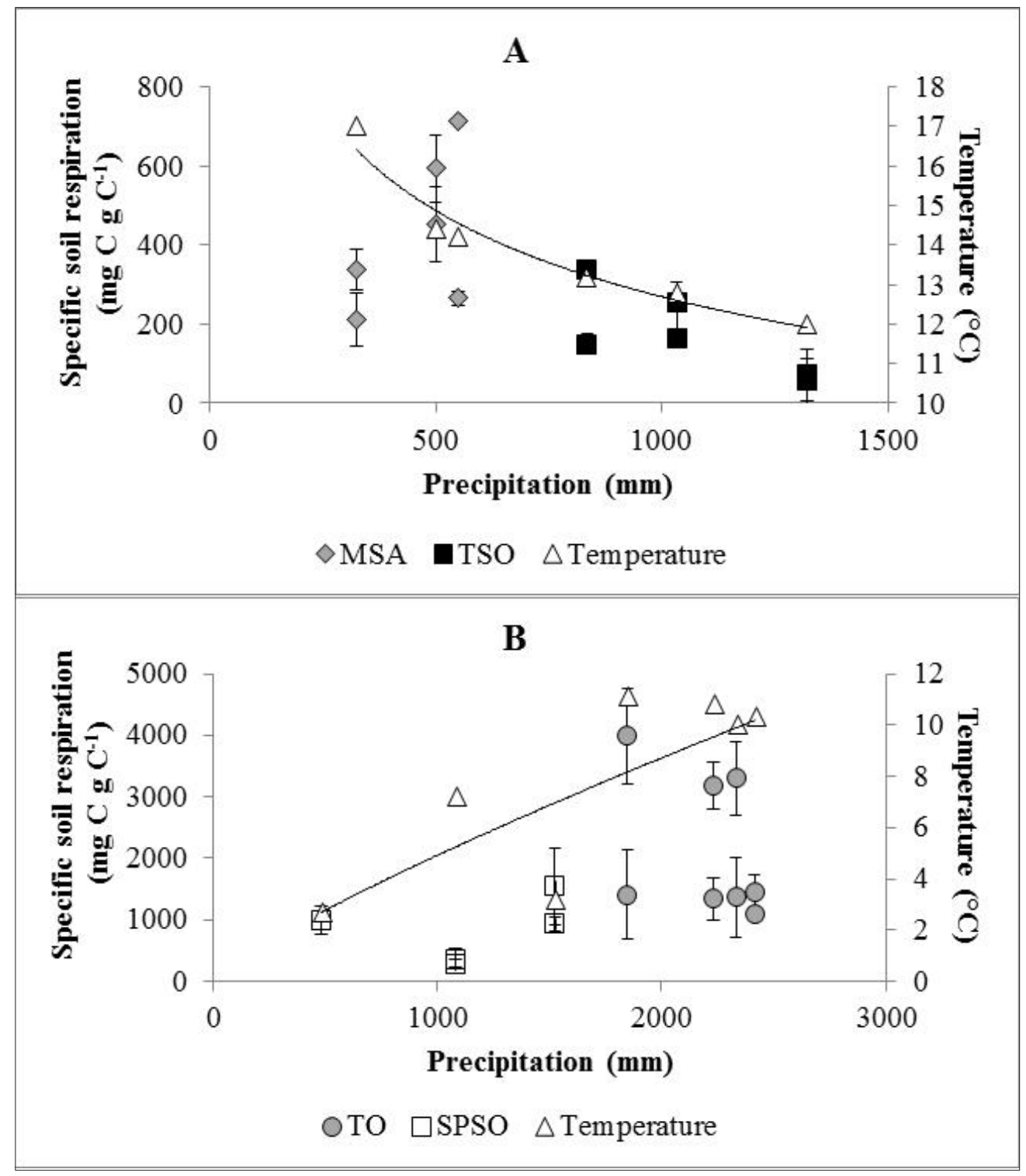

Figure 2. Specific respiration ( $\mathrm{mg} \mathrm{C} \mathrm{g} \mathrm{C}^{-1}$ ) of soils from different climate zones (at $20^{\circ} \mathrm{C}$ ) along a longitudinal transect in Chile, where (A) shows soils from MSA and TSO, and (B) shows soils from TO and SPSO. The lines represent the increase or decrease in temperature along the gradient 


\section{3. $E_{a}$}

The $\mathrm{E}_{\mathrm{a}}$ (Table 4) varied considerably between the soils of each climate study zone with a coefficient of variation $(\mathrm{CV})$ of $44.45 \%$ between the 13 studied soils. When analyzing the mean $\mathrm{E}_{\mathrm{a}}$ values for macroaggregates, no significant differences were observed between climate zones; values ranged between 32.95 and $83.13 \mathrm{~kJ} \mathrm{~mol}^{-1}$ with a $\mathrm{CV}$ of $51.83 \%$.
For free microaggregates, the highest value $(p \leq 0.05)$ was found in soils from the TO zone $\left(80.4 \mathrm{~kJ} \mathrm{~mol}^{-1}\right)$, while MSA and TSO values were less than $54 \%$ of this value. In addition, no significant differences in $\mathrm{E}_{\mathrm{a}}$ values were found between the two soil aggregate classes. The average $\mathrm{E}_{\mathrm{a}}$ of each climate zone was 20.24, 25.91, 42.42 and $81.75 \mathrm{~kJ} \mathrm{~mol}^{-1}$ for MSA, TSO SPSO and $\mathrm{TO}$, respectively.

Table 4. Energy of activation $\left(\mathrm{E}_{\mathrm{a}}\right)$ and $\mathrm{Q}_{10}$ of soil aggregates from different climate zones. Fishers LSD test (p d" 0.05); different letters represent statistical significance between climate zones

\begin{tabular}{|l|r|r|r|r|r|r|}
\hline \multirow{2}{*}{ Climate zone* } & \multicolumn{3}{|c|}{$\mathrm{E}_{\mathrm{a}}\left(\mathrm{kJ} \mathrm{mol}^{-1}\right)$} & \multicolumn{3}{c|}{$\mathrm{Q}_{10}$} \\
\cline { 2 - 7 } & Macroaggregates & \multicolumn{1}{|c|}{$\begin{array}{c}\text { Free- } \\
\text { microaggregates }\end{array}$} & Mean & Macroaggregates & Free- & Mean \\
microaggregates & \\
\hline MSA & $32.95 \mathrm{a}$ & $22.47 \mathrm{~b}$ & $20.24 \mathrm{~b}$ & $1.61 \mathrm{~b}$ & $1.48 \mathrm{~b}$ & $1.39 \mathrm{~b}$ \\
\hline TSO & $40.01 \mathrm{a}$ & $16.52 \mathrm{~b}$ & $25.91 \mathrm{~b}$ & $1.36 \mathrm{~b}$ & $1.41 \mathrm{~b}$ & $1.55 \mathrm{~b}$ \\
\hline TO & $83.13 \mathrm{a}$ & $80.38 \mathrm{a}$ & $81.75 \mathrm{a}$ & $3.22 \mathrm{a}$ & $3.35 \mathrm{a}$ & $3.28 \mathrm{a}$ \\
\hline SPSO & $63.58 \mathrm{a}$ & $43.55 \mathrm{~b}$ & $42.42 \mathrm{~b}$ & $1.63 \mathrm{~b}$ & $1.86 \mathrm{~b}$ & $1.77 \mathrm{~b}$ \\
\hline CV $(\%)$ & 51.83 & 33.4 & 44.45 & 30.70 & 30.78 & 27.91 \\
\hline
\end{tabular}

Climate zone description as in Figure 1. CV: Coefficient of variation

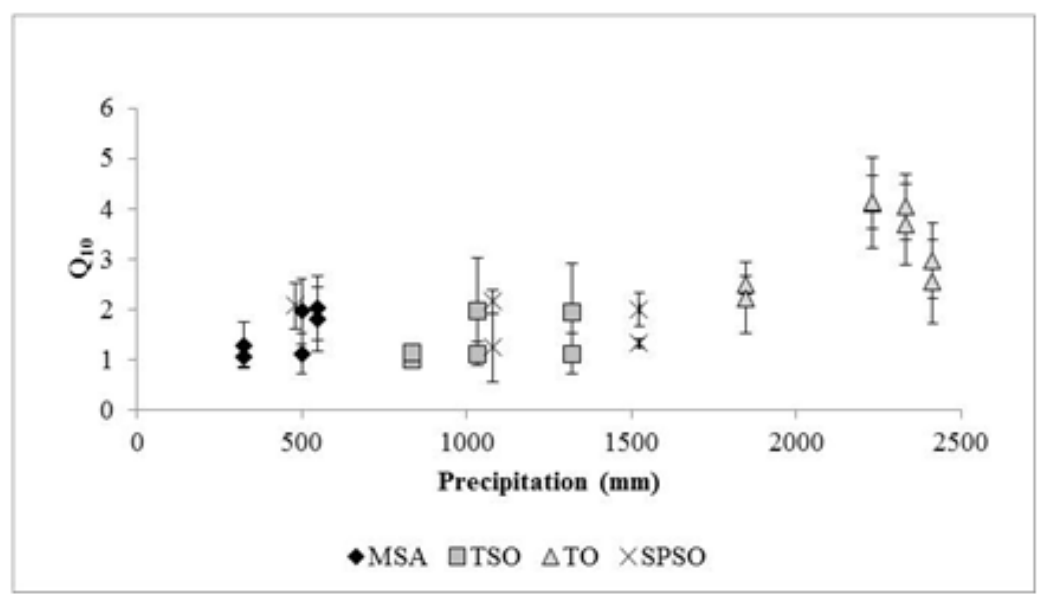

Figure 3. Relationship between annual precipitation and $\mathrm{Q}_{10}$ for macroaggregates $(>250 \mu \mathrm{m})$ and free microaggregates $(50-250 \mu \mathrm{m})$. 


\section{4. $Q_{10}$}

In terms of the sensitivity to organic matter decomposition produced by an increase of $10{ }^{\circ} \mathrm{C}$ (expressed as $\mathrm{Q}_{10}$ value; Table 4; Figure 3), the values ranged from 1.36 to 3.22 for macroaggregates and from 1.41 to 3.35 for free microaggregates with no significant differences between the soil fractions (Table 4). The highest values of $\mathrm{Q}_{10}$ obtained for both macro- and free microaggregates corresponded to TO soils, which were significantly different from the other climate zones $(p \leq 0.05)$. Taking both soil aggregate fractions together, the mean $\mathrm{Q}_{10}$ for the soils from TO was 3.28. In general, the $\mathrm{Q}_{10}$ value increased as precipitation increased; a strong positive correlation $(\mathrm{r}=0.77, p$ $\leq 0.05$ ) was found between $Q_{10}$ and annual precipitation. Soils from zones with low annual precipitation, such as MSA and TSO, presented $\mathrm{Q}_{10}<2$, and the $\mathrm{Q}_{10}$ value was higher than 2 when annual precipitation was higher than $1,155 \mathrm{~mm}$ (TO and SPSO climate zones; Figure 3). These results demonstrate a high temperature sensitivity of $\mathrm{C}$ decomposition in soil aggregates from rainy zones.

\section{Discussion}

\subsection{Effect of weather on soil C mineralization in soil aggregates.}

A high correlation was observed between the specific soil respiration of the study sites and annual precipitation: $\mathrm{C}$ mineralization decreased with increases in precipitation in soils formed in warmer zones (annual mean temperature above $12{ }^{\circ} \mathrm{C}$; Figure $2 \mathrm{~A}$ ) but showed an opposite tendency in soils from colder zones (annual mean temperature from 2.7 to $10.8^{\circ} \mathrm{C}$; Figure 2B). One explanation is that the vegetation of the TO zone (Figure 2B) consists of permanent grasslands that are highly productive $\left(2,500-6,000 \mathrm{~kg} \mathrm{ha}^{-1}\right.$ year-1 ${ }^{-1}$ Ruiz, 1996), resulting in high plant residue inputs into the soils. Thus, higher $\mathrm{C}$ concentration levels in soil aggregates $(10.0 \pm 2.1 \%$ on average; Table 2$)$ were observed in TO compared to soils from MSA and TSO, where grassland productivity ranges from 500 to $1,500 \mathrm{~kg} \mathrm{ha}^{-1}$ year $^{-1}$ (Ruiz, 1996), resulting in lower residue inputs and an average $\mathrm{C}$ value of $3.0 \pm$ $1.7 \% \mathrm{C}$ in soil aggregates (Table 2). In contrast, soils from warmer zones (Figure 2A) presented lower $\mathrm{C}$ respiration (58-713 $\mu \mathrm{g} \mathrm{C} \mathrm{g} \mathrm{C} \mathrm{soil-1)} \mathrm{than} \mathrm{soils} \mathrm{from}$ colder zones (Figure 2B, 287-3,984 $\mu \mathrm{g} \mathrm{C} \mathrm{g} \mathrm{C} \mathrm{soil-1),}$ which demonstrates a high lability or availability of $\mathrm{C}$ organic matter in soils from colder zones. This finding is partially supported by Podrebarac et al. (2016), who, comparing soil-specific respiration in podzolic boreal forest between higher latitude (colder region) and lower latitude (warmer region) sites, determined that soils from warmer regions are less $\mathrm{C}$ bioreactive because they presented a lower cumulative specific respiration than the other soils. While the ecosystem evaluated in the Podrebarac study is different from ours, the concept of organic $\mathrm{C}$ bioavailability can help to elucidate the differences found between colder and warmer zones; in warmer zones, the more labile forms of $\mathrm{C}$ have been lost as $\mathrm{CO}_{2}$, so only recalcitrant forms of $\mathrm{C}$ persist that are less bioavailable to microbial decay. As these authors postulate, the different climate histories during soil formation can be used to predict the temperature sensitivity of $\mathrm{C}$ decomposition with soils formed under warmer and wetter climate conditions exhibiting increased sensitivity. However, Doetterl et al. (2015) recently demonstrated the relevance of the interactions between geochemistry and climate to soil C storage, showing the complexity of ecosystem $\mathrm{C}$ budgets to climate change. In addition, absolute soil respiration rates (Table 3 ) are higher in soils from the TO zone compared with other climate zones, demonstrating the interaction effect between high $\mathrm{C}$ content and the lability of this organic material, which 
is quantified by the $\mathrm{C} / \mathrm{N}$ ratio. In other words, soils from TO and SPSO had lower $\mathrm{C} / \mathrm{N}$ ratios (and therefore higher lability; average $\mathrm{C} / \mathrm{N}$ ratio $=13.5$ ) compared to soils from MSA and TSO, which had average $\mathrm{C} / \mathrm{N}$ ratios of 22.3 and 14.9 for macro- and microaggregates, respectively.

In our study, no differences were found in $\mathrm{C}$ respiration (absolute and specific soil respiration) between soil aggregate fractions, which likely resulted from the fact that all of the evaluated soils are from unaltered natural grassland systems in which the soil structure has not been disrupted. As a result, aggregates preserve their $\mathrm{C}$ content. However, due the short evaluation term (15 days), the respired $\mathrm{C}$ consists mainly of labile forms (e.g., located on the surface of the soil aggregates) and does not include more recalcitrant $\mathrm{C}$ sources, which are protected from decay by physical and/or chemical mechanisms (Blanco-Canqui and Lal, 2004; Six and Paustian, 2014). A biochemical analysis of $\mathrm{C}$ within soil aggregates (C quality) will help to elucidate soil decomposition patterns between soil aggregates and contribute to a better understanding of our results.

\subsection{Temperature sensitivity of $C$ decomposition in soil aggregates}

In this study, no differences in temperature sensitivity to $\mathrm{C}$ decay were found between soil aggregate fractions (Table 4), but this is in contrast to previous research, in which soil incubation periods were longer than in this study (e.g., 60 days or more).

For example, Wang et al. (2015) found differences between soil aggregate fractions from temperate grasslands, observing higher thermal sensitivity in macroaggregates (i.e., higher $\mathrm{E}_{\mathrm{a}}$ and $\mathrm{Q}_{10}$ ) than in other soil fractions. In contrast, Sandeep and Majaiah (2014) obtained higher $\mathrm{E}_{\mathrm{a}}$ and $\mathrm{Q}_{10}$ in microcompared to macroaggregates in two tillage systems under different fertilizer treatments from semi-arid and subtropical zones. Again, this result is likely explained by the duration of the experiment (short-term) and/or by the complex nature of the soil matrix because $\mathrm{C}$ stabilization differs with the type and origin of the soil (Doetterl et al., 2015).

On the other hand, the CQT theory considers the quality of the $\mathrm{C}$ substrate, which explains the sensitivity of decomposition to temperature. This theory has been applied to various bulk soils, but few studies have focused on soil aggregates. To this end, Wang et al. (2015) analyzed macro- and microaggregates from Inner Mongolian temperate grasslands and determined that the CQT theory applied to soil aggregates, indicating that the decomposition of low-quality $\mathrm{C}$ (with higher $\mathrm{E}_{\mathrm{a}}$ ) is more temperature sensitive than that of high-quality $\mathrm{C}$ (with lower $\mathrm{E}_{\mathrm{a}}$ ). In our study, we found that soil fractions with higher $\mathrm{E}_{\mathrm{a}}$ presented a high $\mathrm{Q}_{10}$ value (Table 4), showing higher temperature sensitivity of $\mathrm{C}$ decomposition in soils with more recalcitrant or low-quality organic matter (from a thermodynamic view). However, this is contrary to our soil respiration findings, where soils with a high rate of $\mathrm{C}$ respiration presented higher $\mathrm{E}_{\mathrm{a}}$ (see Tables 3 and 4). Further studies are necessary to study these thermodynamic parameters and associated trends in soils of volcanic origin because these soils, specifically Andisols (6 of the total number of soils), interact with organic molecules through allophone, imogolite-type minerals and aluminum ( $\mathrm{Al})$ and iron $(\mathrm{Fe})$ oxides, which produce $\mathrm{C}$ stabilization in soils. Such stabilization mechanisms, which differ from those of other non-allophanic soils (Matus et al., 2014; Takahashi and Dahlgren, 2016), would mask the true value of $E_{a}$.

The results from our $\mathrm{Q}_{10}$ analysis showed that microbial decomposition in TO soils was more sensitive to an increase in temperature than those at all other sites (Table 4). This result could be partially due to the high precipitation at TO (Table 1) because a 
strong correlation between $\mathrm{Q}_{10}$ and precipitation was observed $(r=0.77$, Figure 3$)$. This phenomenon suggests a comparatively large increase in $\mathrm{CO}_{2}$ emissions in soils from Chile's rainy zones under new global warming scenarios (until 2100), which predict an increase of $3-4{ }^{\circ} \mathrm{C}$ in the global temperature for our southern location (IPCC, 2014). The average value of $\mathrm{Q}_{10}$ for the TO and SPSO areas was $2.70 \pm 1.02$, while soils from MSA and TSO presented a lower mean $\mathrm{Q}_{10}$ value $\left(Q_{10}=1.42 \pm 0.42\right)$. These findings suggest that the $\mathrm{Q}_{10}$ value more than doubles in rainy sites with annual precipitation of at least $1,155 \mathrm{~mm}$.

\section{Conclusions}

Soils can act as either sources or sinks for atmospheric carbon, and this determination is critical to assessing their impact on global warming. Although our results do not provide evidence of differences between soil aggregate fractions in the parameters evaluated, soil aggregate respiration along a north-south gradient in the central-south part of Chile was highly correlated with the annual mean precipitation, indicating the relevance of this factor in the rate of $\mathrm{C}$ decay.

Through the use of the thermodynamic parameter $\mathrm{Q}_{10}$, it was demonstrated that the microbial $\mathrm{C}$ decomposition in soils from rainy zones (the south of Chile) was more sensitive to increases in temperature than that of soils from drier areas. This information could contribute to improving current models of global change.

\section{Acknowledgements}

This study was funded by the Chilean National Fund for Science and Technological Development (Fondecyt) under Regular Project No 1121138 . We also acknowledge Miss Claudia Rivera, chemical analyst, for support in the laboratory.

\section{References}

Balesdent, J., Pétraud, J.-P., Feller, C. 1991. Effects des ultrasons sur la distribution granulométrique des matières organiques des sols. Science Du Sol. 29, 95-106.

Blanco-Canqui, H., Lal, R. 2004. Mechanisms of carbon sequestration in soil aggregates. Crit. Rev. Plant Sci. 23, 481-504.

Casanova, M., Salazar, O., Seguel, O., Luzio, W. 2013. The Soils of Chile. World Soils Book Series, $185 \mathrm{p}$.

Craine, J.M., Fierer, N., McLauchlan, K.K. 2010. Widespread coupling between the rate and temperature sensitivity of organic matter decay. Nat. Geosci. 3, 854-857.

Davidson, E.A., Janssens, I.A. 2006. Temperature sensitivity of soil carbon decomposition and feedbacks to climate change. Nature. 440, 165 - 173.

Di Rienzo, J.A., Casanoves, F., Balzarini, M.G., Gonzalez, L., Tablada, M., Robledo, C.W. 2011. Infostat versión 2011. Grupo InfoStat, FCA. Universidad Nacional de Córdoba. Córdoba, Argentina

Doetterl, S., Stevens, A., Six, J., Merckx, R., Van Oost, K., Casanova Pinto, M., Casanova-Katny, A., Muñoz C., Boudin, M., Zagal Venegas E., Boeckx, P. 2015. Soil carbon storage controlled by interactions between geochemistry and climate. Nat. Geosci. 8, 780-783.

Elliott E.T. 1986. Aggregate structure and carbon, nitrogen, and phosphorus in native and cultivated soils. Soil Sci. Soc. Am. J. 50, 627-633.

Giardina, C.P., Ryan, M.G. 2000. Evidence that decomposition rates of organic carbon in mineral soil do not vary with temperature. Nature. 404 , 858-861.

Guidi, P., Falsone, G., Mare, B.T., Vianello, G. 2013. Relationships between soil microbial biomass, 
aggregate stability and aggregate associated-C: a mechanistic approach. EQA - International Journal of Environmental Quality. 12, 1-16.

IPCC. 2014. Climate Change 2014 Mitigation of Climate Change. Working Group III Contribution to the Fifth Assessment Report of the Intergovernmental Panel on Climate Change. Cambridge University Press, New York.

IUSS Working Group WRB. 2015. World Reference Base for Soil Resources 2014, update 2015. International soil classification system for naming soils and creating legends for soil maps. World Soil Resources Reports No. 106. FAO, Rome.

Lehmann, J., Kinyangi, J., Solomon, D. 2007. Organic matter stabilization in soil microaggregates: implications from spatial heterogeneity of organic carbon contents and carbon forms. Biogeochemistry. $85,45-57$.

Leifeld, J., Fuhrer, J. 2005. The temperature response of $\mathrm{CO} 2$ production from bulk soils and soil fractions is related to soil organic matter quality. Biogeochemistry. 75, 433-453.

Mannetje, L.T. 2002. Advances in grassland science. NJAS- Wageningen Journal of Life Sciences. 50, 195-221.

Matus, F., Rumpel, C., Neculman, R., Panichini, M., Mora, M.L. 2014. Soil carbon storage and stabilisation in andic soils: A review. Catena. 120, 102-110.

Meersmans, J., Wesemael, B. van, De Ridder, F., Van Molle, M. 2009. Modelling the three-dimensional spatial distribution of soil organic carbon (SOC) at the regional scale (Flanders, Belgium). Geoderma. 152, 43-52

Onweremadu E.U., Onyia, V.N., Anikwe, M.A.N. 2007. Carbon and nitrogen distribution in waterstable aggregates under two tillage techniques in Fluvisols of Owerri area, southeastern Nigeria. Soil and Tillage Research. 97, 195-206.
Plante, A.F., Six, J., Paul, E.A., Conant, R.T. 2009. Does physical protection of soil organic matter attenuate temperature sensitivity? Soil Sci. Soc. Am. J. 73, 1168-1172.

Podrebarac, F.A., Laganière, J., Billings, S.A., Edwards, K.A., Ziegler, S.E. 2016. Soils isolated during incubation underestimate temperature sensitivity of respiration and its response to climate history. Soil Biol. Biochem. 93, 60-68.

Ruiz, I. 1996. Praderas para Chile, 2. ed. Instituto de Investigación Agropecuaria y Ministerio de Agricultura, Santiago, 733 p.

Sadzawka, A., Carrasco, M.A., Grez, R., Mora, M.L., Flores H., Neaman, A. 2006. Métodos de análisis recomendados para los suelos de Chile: revisión 2006. Serie Actas INIA N³4. INIA La Platina. Santiago, $164 \mathrm{p}$.

Sandeep, S., Manjaiah, K.M. 2014. Thermal stability of organic carbon in soil aggregates of maizewheat system in semi arid India. J. Soil Sci. Plant Nutr. 14 , 625-639.

Sandoval, M., Dörner, J., Seguel, O., Cuevas, J., Rivera, D. 2012. Métodos de análisis físicos de suelos. Publicaciones del Departamento de Suelos y Recursos Naturales $\mathrm{N}^{\circ} 5$. Universidad de Concepción. Chillán, 80 p.

Six, J., Conant, R.T., Paul, E.A., Paustian, K. 2002. Stabilization mechanisms of soil organic matter: Implications for C-saturation of soils. Plant Soil. 241, 155-176.

Six, J., Paustian, K. 2014. Aggregate-associated soil organic matter as an ecosystem property and a measurement tool. Soil Biol. Biochem. 68: A4A9.

Soil Survey Staff. 1999. Soil taxonomy: A basic system of soil classification for making and interpreting soil surveys. Washington, DC, $886 \mathrm{p}$. 
Starr, G.C., Lal, R., Kimble, J.M. 2001. Fractionating soil in stable aggregates using a rainfall simulator. In: R. Lal, J.M Kimble, R.F. Follet, B.A. Stewart (Eds.). Assessment methods for soil carbon, Washington, D. C. pp: 285-291.

Stockmann, U., Adams, M.A., Crawford, J.W., Field, D.J., Henakaarchchi, N., Jenkins, M., Minasny, B., McBratney, A.B., Remy de Courcelles, V. de, Singh, K., Wheeler, I., Abbott, L., Angers, D.A., Baldock, J., Bird, M., Brookes, P.C., Chenu, C., Jastrow, J.D., Lal, R., Lehmann, J., O’Donell, A.G., Parton, W.J., Whitehead, D., Zimmermann, M. 2013. The knowns, known unknowns and unknowns of sequestration of soil organic carbon. Agr. Ecosyst. Environ. 164, 80-99.

Takahashi, T., Dahlgren, R.A. 2016. Nature, properties and function of aluminum-humus complexes in volcanic soils. Geoderma. 263, 110-121.

Von Lützow, M., Kögel-Knabner, I. 2009. Temperature sensitivity of soil organic matter decompositionwhat do we know?. Biol. Fertil. Soils. 46, 1-15.

Voroney, R.P. 2007. The soil habitat. In: Paul, E.A. (ed.). Soil microbiology, ecology, and biochemistry, 3 ed. Burlington, MA, pp: 25-49.
Wang, Q., Wang, D., Wen, X., Yu, G., He, N., Wang, R. 2015. Differences in SOM decomposition and temperature sensitivity among soil aggregate size classes in a temperate grasslands. PLoS One. 10, 1-12.

White, R., Murray, S., Rohweder, M. 2000. Pilot analysis of global ecosystems: Grassland ecosystems. World Resources Institute, Washington, D. C., 69 p.

Xu, X., Zhou, Y., Ruan, H., Luo, Y., Wang, J. 2010. Temperature sensitivity increases with soil organic carbon recalcitrance along an elevational gradient in the Wuyi Mountains, China. Soil Biol. Biochem. 42, 1811-1815.

Yoo, G., Yang, X., Wander, M.M. 2011. Influence of soil aggregation on SOC sequestration: a preliminary model of SOC protection by aggregate dynamics. Ecol. Eng. 37, 487-495.

Zhang, K., Dang, H., Zhang, Q., Cheng, X. 2015. Soil carbon dynamics following land-use change varied with temperature and precipitation gradients: evidence from stable isotopes. Global Change Biol. 21, 2762-2772. 